\title{
Contemptible Safety: Coronavirus and the Moral Value of Universities?
}

\author{
Mary K. Ryan
}

The onset of the coronavirus created a national panic in the United States. Learning as we go through this new global pandemic has called for fast thinking and quick choices. Emergencies demand action. For many reasons, not the least being the need to protect against large group gatherings and keep students and faculty safe from contracting COVID-19, educational institutions, especially colleges, sent students away from their on-campus learning, living, and other activities, and shifted to online learning. As the scores of special issues make clear, how governments and institutions respond to emergencies offers vital lessons. After all, emergencies do not exist as occasions that suspend our moral principles. Quite the opposite, the way that administrators and leaders handle the unexpected, the extraordinary, and the exceptional demonstrate their true values. I suggest that neoliberalism paints the academic landscape in a way that cultivates a sense that we are being managed, but not informed. This leads people to a position of feeling like strangers who are alienated from their own choices, control over their lives, and like cogs in a machine of progress as usual without intentionality, commitment, or passion. In this way, the academic response to COVID-19 crushes people by uncivilizing them, similar to what has evolved in the prison industrial complex. Fighting neoliberal control of universities and prisons, two institutions intricately wound up in molding minds, must always be a moral challenge. The construction of strangeness reflects the role of morality (specifically through the interchange of compassion and contempt) in negotiating contemporary social and political spaces. In this essay, I first look at the ways in which moral psychology uses emotion to demarcate civil limits. Then, I outline how one major issue in social justice, the prison industrial complex, exemplifies the transformation of identity into strangeness and strangers, justifying harmful public policies. Lastly, I contemplate how theorist Lauren Berlant's philosophy of cruel optimism enables us to better understand institutional politics and individual sovereignty. Ultimately, I argue that universities must remain places for moral democracy to grow, but this demands a transition from contempt to compassion, suggesting that individual connections are the real pathway to social justice, not a reliance on institutional or structural powers.

Numerous university responses to COVID-19 include teaching directives that seem to assume faculty possess equal ability to carry out their tasks. For many-especially contract/ adjunct faculty, differently-abled faculty, and women, and disproportionately women of colorthe pandemic has presented new childcare, eldercare, and homeschooling, and mental health challenges. These inequalities would likely be exacerbated by university proposals that include a hybrid or dual delivery model, where some students in a course come to a physical class and others work remotely. This echoes Wendy Brown's discussion of how neoliberalism warps social and political policy and figures citizens as rational economic actors in all spheres of their lives. Brown states that neoliberalism: 
Entails a host of policies that figure and produce citizens as individual entrepreneurs and consumers whose moral autonomy is measured by their capacity for "self-care"-their ability to provide for their own needs and service their own ambitions, whether as welfare recipients, medical patients, consumers of pharmaceuticals, university students, or workers in ephemeral occupations. (694)

This mode of "self-care" demonstrates a potential risk of universities leaving studentsalong with faculty and staff-to figure out how to adapt without appropriate supports, and even without considering whether adaptation is even an appropriate risk with surging levels of contamination and potential death and illness to members of campus communities. Selfcare models of policymaking and university practice treat people as products, creating a kind of precarity that matches Lauren Berlant's concept of cruel optimism, as I'll discuss later in this article. While everyone at university is impacted by COVID-19, not everyone is impacted in similar ways or to equal degrees. Unless universities accommodate faculty who are less wellpositioned to transform to remote teaching, equity gains, already a tenuous claim, will be lost more readily, leaving those faculty fragmented from the university community, in turn diminishing the solidarity academic institutions need to be welcoming spaces for all students and staff. Although scarcely discussed overtly, teaching models and plans for managing coronavirus at colleges are inseparable from affect and ethics, which frame so much of our community values. University politics in managing COVID-19 can result in some people treated as strangers. Hard Feelings: The Moral Psychology of Contempt outlines how contempt functions as a marker of civility's limits (Bell 2013). Biopolitics feeds on this endpoint of civility's limit, risking a kind of rationality in decision-making that neither seeks nor supports truth nor accountability in university actions. Without unanimous federal protocol and guidance, the higher education system can devolve into a competitive regime of subjective choice around how it manages COVID-19. As such, colleges and universities can be considered actors in the politics of the broader neoliberal order, albeit within the general framework of biopolitics. I suggest the management of the pandemic in higher education is consistent with how Michel Foucault discusses neoliberalism in his classic lecture on The Birth of Biopolitics. Accordingly, I understand neoliberalism to be a regime of subjectification geared towards the production of presumably resilient subjects-like faculty, staff, and students - capable of adapting to the neoliberal mechanisms of production, exploitation, accumulation, and dispossession. In this way, higher education demanding a return to the classroom or face-to-face learning (without sufficient health measures and precautions, including but not limited to mandatory facial masks, temperature testing, disease testing, social distancing, and cleaning), and not creatively and fully preparing for the use of virtual learning platforms (which have shortcomings, but being directly at risk of disease transmission is not one), is a produced crisis. It is understandable that universities and colleges face budgetary shortfalls after sudden operational changes upon the wake of the pandemic. But settling the question of if students and families will front thousands of dollars for a subpar virtual learning environment while sacrificing the health and care for the university environment is not the best answer. We do not need to be in this position. There are choices, but not in this neoliberal mindset and socio-economic order. Disasters-be they from pandemics, political upheaval, or environmental causes-will likely strike higher education again in the future. Although the impulse to re-open and return to old ways is understandable, it is irresponsible to survive by getting by. Overcoming this neoliberal trap requires imagination and preparation for the future, which secures a place for equitable communities. In a recent essay, Honor Brabazon raises an important consideration of how neoliberalism might threaten university practices in the wake of COVID-19. Brabazon observes that:

A guiding principle of neoliberal thought is that citizens should interact as formal equals, without regard for the substantive inequalities between us. This formal equality makes it difficult to articulate needs that arise from historical injustices, for instance, as marginalized groups are seen merely as stakeholders with views equally valuable to those of other stakeholders (2020, para 8) 
Such artificial homogeneity can be alienating. When higher education prioritizes reopening above human life, it suggests that the material product of the university itself and the commodity of education alone, are more important than the lives of those who operate and benefit from the machine. Worse, if these discussions omit nuanced analysis of different populations and how they have been historically treated and impacted differently, and how they will fare differently moving forward without diligent care, institutions of higher education risk perpetuation of longstanding inequity at the expense of just remaining on life support. Alienating people by drawing divisions for the sake of profit preserves the legacy of institutional racism, but on a more grounded level, it has serious concerns for the community and the presence of the stranger. For example, racism creates the stranger through a process in which affective expressions are undergirded by repeated expressions of contempt, causing the racist to entrench a lack of desire to see other people as they are and for what they deserve. As such, the existence of strangers implies important questions about otherness that underpins racism: What does a person deserve by being a person? How does the denial of personhood exclude? And what is lost by being a stranger? Contempt — and related emotions like anger, fear, and disgust-are avenues people sometimes employ to answer these questions, which perpetuate the existence of strangers because they motivate disengagement, thus tearing at the fabric of society and fracturing interpersonal relationships, institutional access, and structure of governmental regimes. The Moral Emotions contends that "as guardians of the moral order, [contempt, anger, and disgust] all.... motivate people to change their relationships with moral violators." (Haidt 2003, 859) More to the point, anger, disgust, and contempt can lead to punishing, blaming, and ostracizing those who are seen as unworthy of deeper compassion and care. Deeming someone a stranger assigns a moral judgment, and the action of scapegoating strangers often follows. In other words, in a sociopolitical landscape, strangers are not just another synonym for people; instead, they signify a special kind of person created to justify forthcoming institutional, political, ideological, or structural measures. It is important to consider the chance that whatever reforms are adopted to manage the pandemic could linger into the future. Inclusive, compassionate measures now bode better for meaningful long-term measures. After all, outcasts and othering are not accidental; such actions signify extensions of moral preferences that are sanctioned by scapegoating. This is not to suggest that the experience of strangeness is without complication. People are indeed sometimes torn between personal feelings and a sense of loyalty to systemic pressures. In Responsibility for Justice, Iris Marion Young describes modern life, especially in urban areas, as characterized by the deliberate repression of human sensitivity. (2013) This sort of willful disconnection allows some to distance themselves from others who are victims suffering from injustice even when it is immediately occurring before us. If we demean or humiliate others, we can justify that those individuals are undeserving of our compassion, in turn holding no claim to our assistance or charity. The risk of purely remote teaching does not simply end with restructuring how students learn. Removing students from supported higher education and turning into a model of education that could undercut faculty and staff supports has greater risks. A belief in the superiority and unequal stature of others who seem strange can suppress instincts toward pity, creating a psychological gap between members of the same society.

The existence of punishment and contempt of people in society suggests that strangeness presumes an appropriate code of conduct has been violated. In this way, strangeness raises crucial considerations about political efficacy, especially in democratic governments and university decisions of how to best educate during a pandemic Strangeness troubles participatory governance and collective decision-making, and more broadly nationalism and patriotism, because it distances people from the ability to influence effective solutions to societal problems. In fact, the creation of strangers transcends infrastructure, resources, and policies altogether, suggesting individual people themselves are the problem. Strangeness breeds contempt by instilling fear into us that strangers will never not be strange. The strange can carry ideological weight, as evidenced by the way whiteness undergirds public policy through structural racism. White supremacy sabotages the inclusiveness of all races, perpetuating domination through messages and delusions that people of color as strange, and strangers are to be avoided. This echoes what is crafted by "the 
racial contract":

One could say, then, as a general rule, that white misunderstanding, misrepresentation, evasion, and self-deception on matters related to race are among the most pervasive mental phenomena of the past few hundred years, a cognitive and moral economy physically required for conquest, colonization, and enslavement. And these phenomena are in no way accidental, but prescribed by the terms of the Racial Contract, which requires a certain schedule of structured blindnesses and opacities in order to establish and maintain the white polity. (Mills 1997, 19; capitalization and emphasis original)

This foundational premise of whiteness frames contemporary sociopolitical encounters and how people encounter each other. In a way, racism can be viewed as the manifestation of the polity of whites' feelings that non-whites are strange. But it surely seems to extend to other identity types, like gender, sexuality, class, and religion, as well. Acknowledgment of broad categories of otherness becomes actionable as othering. Scapegoating is transmuted into oppressive policies, indifference, and intolerance, which bear devastating consequences - not the least of which is the further justification for the entrenchment of ongoing strangeness. Once contempt is established, it seems to expand like a self-fulfilling prophecy or an ever-nurtured feedback loop. As Mills intimates above, strangeness can serve to justify and preserve political ideologies and governmental projects, including higher education responses to COVID-19 that seek profit preservation above human life.

We need not wait for the risk of university failure to COVID-19 to see public policy failure. The prison industrial complex is one example of how identity politics of race, sexuality, gender, and class complicate public policy. The effective understanding of incarcerated individuals in society as being wholly immoral people - not simply people who have committed immoral acts - often leads to prisoners being depicted as a particularly strange subgroup of the population. The citizenry at-large is painted a skewed, incomplete, and dramatic picture of prisons. Towards this end, anthropologist Lorna Rhodes describes prisons as an "absent site." (Rhodes 2001, 65) Prisons and criminals are not represented by mass media in their entirety, nor do mass media portrayals represent real life in prison. Instead, mass media circulates themes or images which trigger and reinforce feelings and beliefs which resonate with the public, based on their preconditioned depictions: violence, prison bars, and uniforms. For example, consider the best-selling video game Prison Tycoon 4: Supermax, which presents this tagline as a challenge to consumers: "Build a profitable privately-run prison from the ground up. Grow your facility to Supermax capabilities, housing the most dangerous and diabolical criminals on earth - all for the bottom line." Such stereotypical fragments, layered on top of the latent philosophies of power and whiteness described in the preceding paragraphs, are used to sensationalize prison life by invoking and engraining racialized and xenophobic fears. Identity politics reveals the isolation and punishment of the other or the stranger. Nations sometimes build policy around the maintenance and sustained construction of what Charles Mills's outlines as a racial contract, and ultimately, the prison industrial complex is an example of this bigoted mindset. The prison industrial complex thrives on the ability to cordon off certain citizens and illustrates a way people respond to others that are different from us or that we hold contempt for within society. If we are not careful, higher education risks to replicate this disposability model in the name of profit alone.

The risk of an ever-present stranger arising from emergency remote learning and an already robust prison industrial complex evokes Lauren Berlant's writing on cruel optimism. Cruel optimism comes about when individuals remain attached to "conditions of possibility" or "clusters of promises," which are embedded in desired objects or ideas, even when those same objects or ideas inhibit people from acquiring or fulfilling such items or promises. (Berlant 2011, 23 and 24) Berlant groups unachievable fantasies of the good life into four categories: promises of upward mobility, job security, political and social equality, and durable intimacy. (Berlant 2011, 3) These four criteria constitute what liberal-capitalist societies claim people must possess in order 
to make life add up to something. With the emergence of othering and strangeness support, the problem is that society can no longer provide sufficient opportunities for individuals to achieve such flourishing. Berlant's primary inquiry is into these fantasies of the good life, and she spends much of the book grappling to understand how and why individuals cling to false promises. The role of institutions is implicitly woven throughout Berlant's book. Most directly, she uses the phrase "precarious public sphere" to delimit the site upon which cruel optimism is played out. (Berlant 2011, 3) In this space, we see "an intimate public of subjects who circulate scenarios of economic and intimate contingency and trade paradigms for how best to live on." (Berlant 2011, 3) Berlant presents a politically-motivated concept of the historical present as a means to understand what forces are responsible for whatever urgent crises have taken hold. She does not fully develop objections to specific institutions that she deems culpable for the calamities she examines; instead, she broadly hangs her argument on liberal-capitalist societies in Europe and the United States. For this reason, it seems Berlant agrees with Bourdieu's claim that the state has a monopoly of power to carry out both legitimate and symbolic violence. Bourdieu observes that "state bureaucracies and their representatives are great producers of 'social problems"" (Bourdieu 1994, 2), and such "social problems" are reflected in Berlant's examination of "precarious bodies, subjectivity, and fantasy in terms of citizenship, race, labor, class (dis)location, sexuality, and health." (Berlant 2011, 3) Bourdieu, drawing on Weber, argues that "the state is an X (to be determined) which successfully claims the monopoly of the legitimate use of physical and symbolic violence over a definite territory and over the totality of the corresponding population." (Bourdieu 1994, 3) While Berlant does not make the connection to Bourdieu that is being drawn here, and thus never declares these allusions to state control directly, she nevertheless ensconces Bourdieu's logic by placing total blame on the state for the "retraction of the social-democratic promise of the post-Second World War period in the United States and Europe." (Berlant 2011, 3) Bourdieu and Berlant go hand-in-hand, illustrating the effect of fractured state policies and state violence practiced on a population in the context of social norms of optimism.

If society is to rescue the stranger, and we are to revitalize the love of the strange in a way that can advance unique personal contributions rather than anonymous knowledge hoarding and assimilation, I argue it must move beyond state policies and state violence into a discussion of sovereignty. Berlant seeks to move beyond structure, agency, and disruption into a new mode of analysis, which examines "adjudication, adaptation, and improvisation" amid the status quo, what she dubs "a crisis-defined and continuing now." (2011, 54) Although Berlant does not extrapolate universally, she does seem to suggest that no one can escape an affective mediation with the historical present: "there is no place sufficiently under the radar to avoid the insult that the world is not organized around your sovereignty." (2011, 85) Personal identity is intimately associated with sovereignty, as "one has only been loaned a name and biography and personality and meaningfulness, and that that loan could be recalled not just by death but by the cruel forces of life, which include randomness but which are much more predictable, systemic, and world-saturating than that too." (Berlant 2011, 91) Despite the power of the strange to seep into governing principles, it seems the avenue toward mitigating or diluting its power must be derived through interpersonal trust.

Humane treatment amidst neoliberal institutions is not guaranteed to any of us. Compassion is a choice that social justice demands we cultivate. The pandemic pushes colleges, universities, and other partners to step back and question things like: What are the changing needs of schools, students, and parents? What is needed now and what will be needed in the future? How can we scale our work to best meet these needs? What would best benefit marginalized communities? When people fear how universities might (likely) respond to COVID-19, they fear the pervasiveness of neoliberalism, which leaves people to be managed, stockpiled, and puppeteered. There is no ethical value to keeping universities open, in a virtual platform or a brick-and-mortar space, if they become void of morality and just exist to line the pockets of system presidents and trustees. The emergency response to the coronavirus reveals what we value. Universities are vital to a democratic society, helping to teach students the value of critique and cultivate educated, aware, 
and ethical citizens. Eschewing community, collaborative decision-making, and compassionate choices would leave a moral void which will sour what remains of our democratic society long after this particular pandemic is conquered. 


\section{References}

Bell, Macalester. 2013. Hard Feelings: The Moral Psychology of Contempt. New York: Oxford University Press.

Berlant, Lauren. 2011. Cruel Optimism. Durham: Duke University Press.

Bourdieu, Pierre. 1994. "Rethinking the State: Genesis and Structure of the Bureaucratic Field." Sociological Theory 12 (1). [American Sociological Association, Wiley, Sage Publications, Inc.]: 1-18. Web. doi:10.2307/202032.

Brabazon, Honor. May 29, 2020. The academy's neoliberal response to COVID-19: Why faculty should be wary and how we can push back. Academic Matters. Accessed online at https://academicmatters.ca/ neoliberal-response-to-covid-19/.

Brown, Wendy. American Nightmare: Neoliberalism, Neoconservatism, and De-Democratization. Political Theory. Vol. 34, No. 6 (Dec., 2006), pp. 690-714.

Foucault M. (2010) The Birth of Biopolitics: Lectures at the Collège de France, 1978-79 (trans. Burchell G.). Basingstoke: Palgrave Macmillan.
Haidt, Jonathan. (2003). The moral emotions. In R. J. Davidson, K. R. Scherer, \& H. H. Goldsmith (Eds.), Handbook of affective sciences. Oxford: Oxford University Press. (pp. 852-870).

Rhodes, Lorna A. "Toward an anthropology of prisons," Annual Review of Anthropology 30 (October 2001): 65-83. doi:10.1146/annurev.anthro.30.1.65

Young, Iris Marion. 2013. Responsibility for Justice. New York: Oxford University Press. 
